\title{
Molecular and morphological data resurrect the long neglected Carex laxula (Cyperaceae) and expand its range in the western Mediterranean
}

\author{
Carmen Benítez-Benítez ${ }^{1, *}$, Mónica Míguez ${ }^{1}$, Pedro Jiménez-Mejías ${ }^{2} \&$ Santiago Martín-Bravo $^{1}$ \\ ${ }^{1}$ Área de Botánica, Departamento de Biología Molecular e Ingeniería Bioquímica, Universidad Pablo de Olavide, ctra. de Utrera km 1 s.n., \\ 41013 Seville, Spain; cbenben1@upo.es \\ ${ }^{2}$ New York Botanical Garden, 2900 Southern Blvd., Bronx, NY 10458, USA
}

\begin{abstract}
Benítez-Benítez, C., Míguez, M., Jiménez-Mejías, P. \& MartínBravo, S. 2017. Molecular and morphological data resurrect the long neglected Carex laxula (Cyperaceae) and expand its range in the western Mediterranean. Anales Jard. Bot. Madrid 74(1): e057.

Carex sylvatica subsp. paui is a poorly studied taxon considered endemic from a few places in the western Mediterranean. It has been frequently misidentified as $C$. sylvatica subsp. sylvatica. To date, it has been reported only from the NE Iberian Peninsula and the NW Africa. We use molecular - nuclear ribosomal and plastid sequences - and morphological data to shed light on the taxonomic circumscription and distribution of this taxon, especially regarding its distinction from the type subspecies. The genetic data support the recognition of $C . s y l-$ vatica subsp. paui as an independent taxon, and confirm new records from the Balearic and Tuscan archipelagos. It implies a considerable increase in its range and a new taxon for the Italian flora. Strikingly, the morphometric analyses revealed that the Sicilian type specimen of C. laxula identifies this species with C. sylvatica subsp. paui. We consider that the taxon should be ranked at the species level. Based on the priority of the name C. laxula over C. paui, we subsume C. sylvatica subsp. paui in C. laxula. We also provide notes on the ecology of the species.
\end{abstract}

Keywords: Balearic archipelago, Carex sect. Sylvaticae, ITS, Mediterranean flora, taxonomy, Tyrrhenian, Tuscan archipelago, 5'trnK.

\begin{abstract}
Resumen
Benítez-Benítez, C., Míguez, M., Jiménez-Mejías, P. \& Martín-Bravo, S. 2017. Datos moleculares y morfológicos resucitan la olvidada Carex laxula (Cyperaceae) y aumentan su área de distribución en la cuenca mediterránea occidental. Anales Jard. Bot. Madrid 74(1): e057.
\end{abstract}

Carex sylvatica subsp. paui es un taxon poco estudiado considerado endémico de unos pocos lugares del oeste del Mediterráneo. Ha sido frecuentemente confundida con C. sylvatica subsp. sylvatica. Hasta la fecha, se ha citado solo del noreste de España y el noroeste de África. Utilizamos datos moleculares - secuencias nucleares y plastiales- y morfológicos para estudiar la delimitación taxonómica y distribución de este taxon, especialmente en relación con la subespecie tipo. Los datos genéticos apoyan el reconocimiento de C. sylvatica subsp. paui como un taxon independiente y confirman su presencia en los archipiélagos baleárico y toscano. Esto implica un considerable aumento de su área de distribución y un nuevo taxon para la flora italiana. Sorprendentemente, los análisis morfométricos han mostrado que el espécimen siciliano y tipo de C. laxula es $C$. sylvatica subsp. paui. Consideramos que este taxon debería ser reconocido al nivel de especie. Dada la prioridad del nombre C. laxula sobre C. paui, sinonimizamos C. sylvatica subsp. paui a C. laxula. Además, proporcionamos información sobre la ecología de esta especie.

Palabras clave: Archipiélago balear, archipiélago toscano, Carex sect. Sylvaticae, flora mediterránea, ITS, taxonomía, tirreno, 5’trnK.

ORCID ID: C. Benítez-Benítez (http://orcid.org/0000-0003-4956-0343); M. Míguez (http://orcid.org/0000-0002-4321-2121); P. Jiménez-Mejías (http:// orcid.org/0000-0003-2815-4477); S. Martín-Bravo (http://orcid.org/0000-0003-0626-0770).

Received: 15-XII-2015; accepted: 8-XI-2016; published online: 12-VI-2017; Associate Editor: Pilar Catalán.

Copyright: (C) 2017 CSIC. This is an open-access article distributed under the terms of the Creative Commons Attribution-Non Commercial (by-nc) Spain 3.0 License.

\section{INTRODUCTION}

The genus Carex L. - with more than 2,000 speciescomprises about $40 \%$ of the total number of taxa of the family Cyperaceae (Reznicek, 1990; Global Carex Group, 2015). It has a cosmopolitan distribution, with most species diversity distributed in temperate regions of the Northern Hemisphere. Carex sect. Sylvaticae Rouy is a morphologically well-defined small section that currently comprises 6 species (Table 1) distributed in temperate Europe, western Asia, northern and southern Africa. It is placed in $C$. subg. Carex, and is nested in a well-supported clade together with $C$. sect. Rhynchocystis Dumort., $C$. sect. Ceratocystis Dumort., C. sect. Spirostachyae Drejer ex Bailey, and $C$. sect. Rostrales Meinsh. (Global Carex Group, 2016). Carex sylvatica Huds. is native to the Old World and it is the most widespread species of $C$. sect. Sylvaticae, being distributed in Europe, western Asia, and northern Africa; it has also been reported as introduced in North America and New Zealand (Govaerts \& al., 2016). Three subspecies are currently recognized within C. sylvatica: C. sylvatica subsp. sylvatica, C. sylvatica subsp. latifrons (V.I. Krecz.) Ö. Nilsson, and C. sylvatica subsp. paui (Sennen) A. Bolòs \& O. Bolòs (Egorova, 1999; Jiménez-Mejías \& Luceño, 2011). Carex sylvatica subsp. sylvatica is widely distributed across most Atlantic and Eurosiberian Europe and western Asia (Egorova, 1999;

* Corresponding author 
Table 1. Taxonomic treatment of $C$. sect. Sylvaticae according to Egorova (1999), Jiménez-Mejías \& Luceño (2011), and Martín-Bravo \& al. (2013), modified after the results of this study and Global Carex Group (2016). Synonyms at species level follow Govaerts \& al. (2016).

\begin{tabular}{|c|c|c|}
\hline Accepted taxa & Synonyms & Global distribution \\
\hline C. cretica Gradst \& J. Kern & & Crete \\
\hline C. hypaneura V.I. Krecz. & & Southern Caucasus \\
\hline C. laxula Tineo ex Boott & $\begin{array}{l}\text { C. algeriensis Nelmes; C. paui } \\
\text { Sennen }\end{array}$ & $\begin{array}{l}\text { Western Mediterranean: northeastern Spain, Balearic Islands, Tuscan } \\
\text { archipelago, northeastern Algeria, northern Tunisia, and Sicily }\end{array}$ \\
\hline C. rainbowii Luceño \& al. & & South Africa \\
\hline C. sylvatica Huds. subsp. sylvatica & & Europe to western Asia \\
\hline $\begin{array}{l}\text { C. sylvatica subsp. latifrons } \\
\text { (V.I. Krecz) Ö. Nilsson. }\end{array}$ & C. latifolia Boiss. \& Balansa & Northeastern Anatolia, Georgia, and adjacent Caucasus (Nilsson, 1985) \\
\hline C. vulcani Hochst. ex Seub. & & Azores archipelago \\
\hline
\end{tabular}

Jiménez-Mejías \& Luceño, 2011). Carex sylvatica subsp. latifrons is distributed in southwestern Asia, from Turkey to the western Caucasus, and inhabits forests and wet meadows (Nilsson, 1985). Eventually, C. sylvatica subsp. paui has been considered a Mediterranean element with a hitherto known distribution restricted to the northeastern Iberian Peninsula - Catalonia and Navarra(Bolòs \& Vigo, 2001; Luceño \& al., 2008; Aizpuru \& al., 1999, Jiménez-Mejías \& Luceño, 2011), and northwestern Africa - Algeria and Tunisia- (Jiménez-Mejías \& Luceño, 2011; Martín-Bravo \& al., 2013).

Despite being an especially well-known area from the floristic point of view, the Mediterranean region is still revealing some taxonomic and biogeographic novelties. Such new findings have been especially remarkable in family Cyperaceae due to its complicate taxonomy. Recent studies have revealed the presence of previously unknown species in different areas - v.gr., Schoenoplectus corymbosus (Roth ex Roem. \& Schult) J. Raynal (JiménezMejías \& al., 2007) and Cyperus glaber L. (Verloove \& Mesterházy, 2013) in Spain, Cyperus erythrorrhizos Muhl. (Verloove \& Saiani, 2015) alien in Italy, and C. castroviejoi Luceño \& Jim. Mejías (Jiménez-Mejías \& Luceño, 2009) in Greece.

The finding of $C$. sect. Sylvaticae materials resembling C. sylvatica subsp. paui from the Balearic and Tuscan Archipelagos and Sicily led us to conduct a revision of the taxonomy of $C$. sylvatica-like plants in the western Mediterranean. Interestingly, the voucher from Sicily is the type material of $C$. laxula Tineo ex Boott, which has been to date considered a synonym of $C$. sylvatica subsp. sylvatica (Govaerts \& al., 2016).

In this paper we use sequences from two genomes - nrDNA ITS and ptDNA 5'trnK - and morphological data from herbarium specimens to clarify the identity of these taxonomically problematic populations. These molecular regions have been widely and successfully used for systematic purposes in Carex, including C. sect. Sylvaticae (Martín-Bravo \& al., 2013) and other closely related groups (v.gr., Escudero \& Luceño, 2009; Jiménez-Mejías \& al., 2012). Interestingly, to the best of our knowledge, C. sylvatica subsp. paui has never been included in a molecular phylogenetic study. We aim to gain insights on the taxonomic delimitation and geographic distribution of $C$. sylvatica subsp. paui, especially in regards to its distinction from its close relative C. sylvatica subsp. sylvatica.

\section{MATERIAL AND METHODS}

\section{Molecular study}

We performed a phylogenetic reconstruction to infer the phylogenetic placement of the Balearic and Tuscan individuals and to assess the degree of genetic differentiation between C. sylvatica subsp. sylvatica and C. sylvatica subsp. paui. Our sampling (Appendix 1) included: 18 samples of C. sylvatica subsp. sylvatica, selected to representatively cover its distribution area; 5 samples previously classified as C. sylvatica subsp. paui from northwestern Africa and northern Spain; 3 samples of the C. sylvatica subsp. pauilike plants from the Balearic and Tuscan Archipelagos; 4 samples of two other species of $C$. sect. Sylvaticae $-C$. rainbowii and $C$. cretica-; and 6 samples representing two species of each of the three sections phylogenetically closely related to $C$. sect. Sylvaticae (Waterway \& Starr, 2007; Martín-Bravo \& al., 2013): C. demissa Hornem. and C. flava L. - C. sect. Ceratocystis-; C. distans L. and C. punctata Gaudin - C. sect. Spirostachyae_; C. pendula Huds. and C. bequaertii De Wild. - C. sect. Rhynchocystis- DNA was extracted from the specimens using a DNeasy Plant Mini Kit - Qiagen-. Materials were PCR-amplified following PCR conditions from Escudero \& Luceño (2009). Sequence chromatograms were visualized and edited using the program Geneious v. 6.1.7 - Biomatters- Two matrices were built, one containing the ITS sequences — nrDNA matrix - and the second containing the 5'trn K sequences ptDNA matrix - . Informative indels were coded as binary characters. We performed Maximum Likelihood - $\mathrm{M}$ L - and Bayesian Inference - BI- phylogenetic analyses on each matrix as explained in Escudero \& al. (2008), Martín-Bravo \& al. (2013), and Villaverde \& al. (2015) for the ITS and 5'trnK datasets individually. ML analyses were run with RAxML v. 7.2.6 (Stamatakis, 2010), using a GTR+GAMMA model of sequence evolution, as implemented in a Phylocluster - California Academy of Sciences- Bootstrap support for branches was calculated through 1,000 replicates. BI analyses were run with MrBayes v. 3.2.5 (Ronquist \& Huelsenbeck, 2003). Four simultaneous Markov Chain Monte Carlo - MCMC - chains were run for 5 million generations, sampling trees every 100 generations. The simplest models of nucleotide evolution that best fit the data for each studied DNA region were HKY for $5^{\prime} \operatorname{trnK}, \mathrm{HK}$ + I for ITS1 and ITS2, and JC for 5.8S region. Characters corresponding to coded indels were analysed 
with a F81 model. Congruence between the two resulting topologies was checked by eye and using Hompart test as implemented in PAUP* v. $4.0 \mathrm{~b} 10$ (Swofford, 2002) in the same Phylocluster - California Academy of Sciences-. As no significant incongruences were found, the two data sets were combined into a total evidence matrix - combined matrix -, which was analysed again with ML and BI using the same parameters stated above. In order to assess and compare the degree of genetic differentiation between the studied taxa of $C$. sect. Sylvaticae, we calculated pairwise Kimura-2-parameter genetic distances between pairs of samples with MEGA v. 5.2 (Tamura \& al., 2011), using the ITS, 5'trnK, and concatenated sequences.

\section{Morphological study}

22 herbarium specimens of typical C. sylvatica subsp. sylvatica (Appendix 1) and 11 specimens previously classified as C. sylvatica subsp. paui (Appendix 1; including the 3 vouchers from the Balearic and Tuscan Archipelagos, and the type of $C$. laxula from Sicily) were included in our study. For the morphological characterization of the materials we measured the diagnostic characters reported in previous taxonomic studies of C. sylvatica and allied taxa (Chater, 1980; Nilsson, 1985; Luceño \& al., 2008; Egorova, 1999; Martín-Bravo \& al., 2013), as well as additional characters derived from our observations, making a total of 32 quantitative and one qualitative traits (Table 2). Measurements were taken using a binocular micrometer -Nikon SMZ645-, with the exception of the largest macromorphological characters, which were measured using a standard $30-\mathrm{cm}$ rule.

All statistical analyses of morphometric data were performed using the software SPSS Statistics 20 -IBM Corp., New York, Armonk- First, we chose those variables with a higher correlation level $\longrightarrow 0.8-$. Secondly, we removed those variables that contributed less to the first significant principal components. When those characters were removed, a clear morphological discontinuity was found between the 2 subspecies as analyzed through Principal Component Analysis -PCA- A total of 7 variables were kept for the final analysis. We performed boxplot analysis for these variables in order to show the degree of overlapping between the two studied taxa. In the boxplot analysis the Navarran samples previously classified as C. sylvatica subsp. paui were treated as C. sylvatica subsp. sylvatica — see Results.

\section{RESULTS}

\section{Molecular study}

ITS and 5'trnK sequences from the 3 problematic C. sylvatica subsp. paui-like specimens from the Balearic and Tuscan archipelagos clustered with those from typical specimens from northwestern Africa and northeastern Spain - Catalonia-, both in separate - nuclear vs. plastid data sets - and combined analyses (Figs. 1, 6, 7). The northern Spanish Navarran samples, previously classified as C. sylvatica subsp. paui, however grouped with $C$. sylvatica subsp. sylvatica. The phylogenetic relationships revealed by the separate nrDNA and
Table 2. Variables included in the morphometric analysis reported as potential diagnostic characters $\left[{ }^{1}\right.$ The longest flowering stem is measured up to the beginning of the upper male spike; ${ }^{2}$ three measures were taken in each character - base, center, and beak of the glume-; ${ }^{3}$ measures taken from three different utricles].

\begin{tabular}{|c|c|}
\hline $\begin{array}{l}\text { Continuous quantitative } \\
\text { variable }\end{array}$ & Description (measure) \\
\hline SW & Stem width (mm) \\
\hline $\mathrm{SL}^{1}$ & Stem length $(\mathrm{cm})$ \\
\hline LeafW & Leaf width (mm) \\
\hline LeafL & Leaf length $(\mathrm{cm})$ \\
\hline LL & Ligule length (mm) \\
\hline INFL $^{1}$ & Inflorescence length $(\mathrm{cm})$ \\
\hline BRINFLW & Inflorescence bract width (mm) \\
\hline BRINFLL & Inflorescence bract length $(\mathrm{cm})$ \\
\hline MSW & Male spike width (mm) \\
\hline MSL & Male spike length (mm) \\
\hline FSW & Female spike width (mm) \\
\hline FSL & Female spike length (mm) \\
\hline $\mathrm{MGW}^{2}$ & Male glume width (mm) \\
\hline $\mathrm{MGL}^{2}$ & Male glume length (mm) \\
\hline $\mathrm{MGBL}^{2}$ & Male glume beak length (mm) \\
\hline $\mathrm{FGW}^{2}$ & Female glume width (mm) \\
\hline $\mathrm{FGL}^{2}$ & Female glume length (mm) \\
\hline FGHMW $^{2}$ & Female glume hyaline margin width $(\mathrm{mm})$ \\
\hline $\mathrm{UW}^{3}$ & Utricle width (mm) \\
\hline $\mathrm{UL}^{3}$ & Utricle length (mm) \\
\hline BULMW $^{3}$ & Base utricle length to maximum width (mm) \\
\hline $\mathrm{SUL}^{3}$ & Stigma utricle length (mm) \\
\hline $\mathrm{UBL}^{3}$ & Utricle beak length (mm) \\
\hline $\mathrm{ACHW}^{3}$ & Achene width (mm) \\
\hline $\mathrm{ACHL}^{3}$ & Achene length (mm) \\
\hline $\mathrm{SAL}^{3}$ & Stipe achene length (mm) \\
\hline \multicolumn{2}{|c|}{ Discrete quantitative variable } \\
\hline SPKMN & Male spikes number \\
\hline SPKFN & Female spikes number \\
\hline SPKAN & Androgynous spikes number \\
\hline BUN & Beaks utricle number \\
\hline NUN & Nerves utricle number \\
\hline PBUN & Prickles beak utricle number \\
\hline \multicolumn{2}{|l|}{ Qualitative variable } \\
\hline PAP & Presence/absence papillae on the upper leaf \\
\hline
\end{tabular}

ptDNA trees and the combined tree were slightly different (Figs. 1, 6, 7), though they were not significantly incongruent after the Hompart test $-\mathrm{p}>0.05-$. The topology of the combined tree mostly agreed with the one yielded by the nrDNA data due to the higher number of informative characters from this data set in comparison with those from the ptDNA data set (Table 3). Carex sect. Rhynchocystis was strongly supported as sister group to $C$. sect. Sylvaticae in the combined and nrDNA tree -1.0 PP, 100\% BS; 1.0 PP, 98\% BS; Fig. 1 and 7, respectively-, whereas in the ptDNA tree $C$. sect. Rhynchocystis and C. sect. Ceratocystis were resolved as sister groups and in turn sister to $C$. sect. Sylvaticae, 


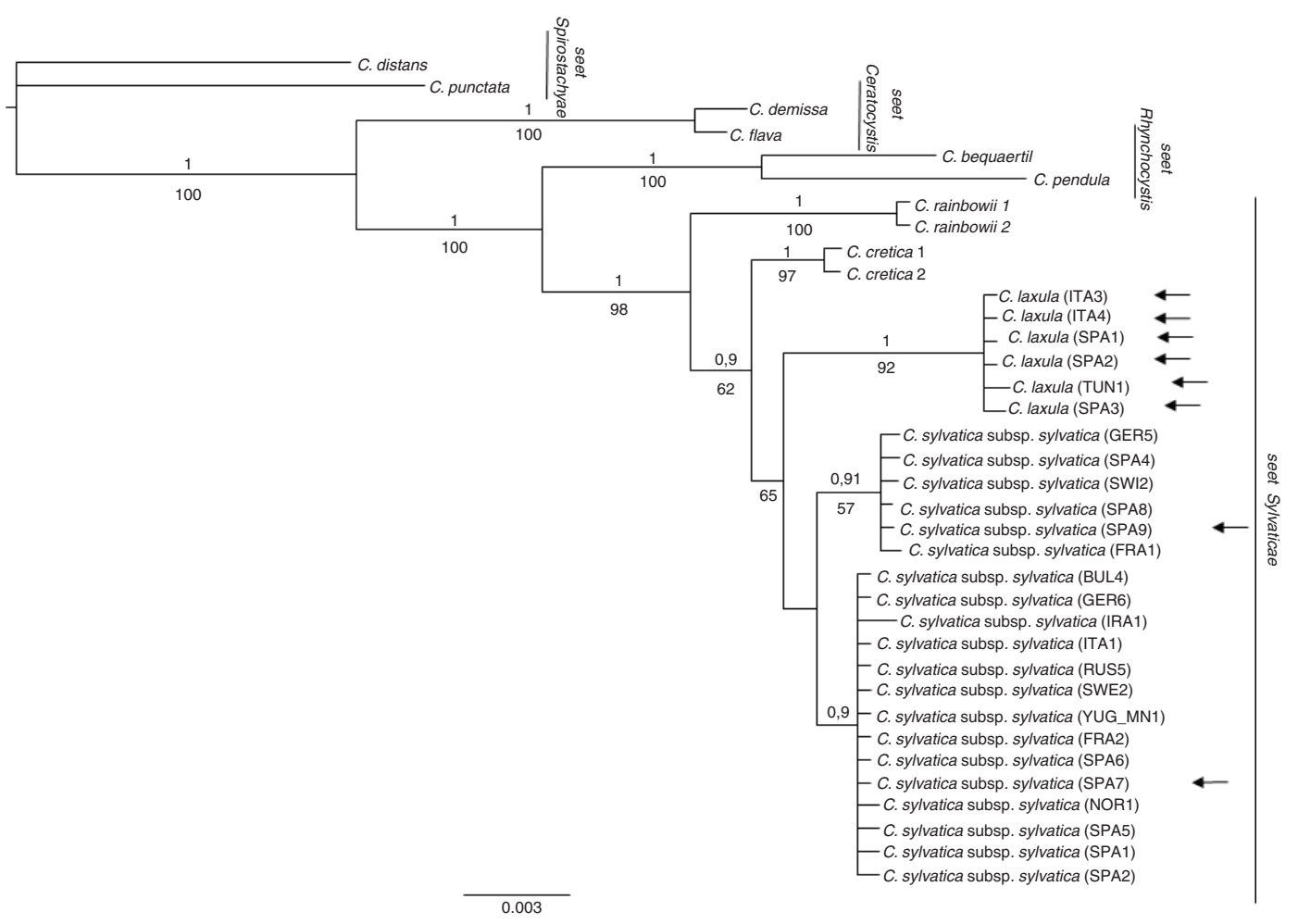

Fig. 1. Bayesian phylogenetic tree obtained from the concatenation of nrDNA ITS and ptDNA 5'trnK sequences for $C$. sect. Sylvaticae -incl. C. cretica, C. laxula, C. rainbowii, and C. sylvatica subsp. sylvatica - and closely related sections - C. sect. Ceratocystis, C. sect. Spirostachyae, and C. sect. Rhynchocystis - . [36 samples were included in this analysis; numbers above or below branches correspond to the posterior probability - PP $>0.9$, above branches - and Bootstrap support - BS > 50\%, below branches — values; arrows depict the samples previously classified as C. sylvatica subsp. paui.]

Table 3. Summary statistics of the analysed molecular markers. Informative sites have been considered only for ingroup sequences.

\begin{tabular}{lccccc}
\hline Molecular markers & $\mathbf{5}$ trnK & ITS & ITS 1 & 5.8 S & ITS 2 \\
\hline Lenght aligned matrix (pb) & 651 & 614 & 225 & 159 & 230 \\
Number of sequences & 32 & 29 & 29 & 29 & 29 \\
Indels (pb) & $5(1-8)$ & $1(1)$ & 1 & 0 & 0 \\
Conserved sites & 607 & 525 & 175 & 157 & 193 \\
Variable sites & 46 & 89 & 50 & 2 & 37 \\
Informative sites & 27 & 63 & 38 & 2 & 23 \\
\hline
\end{tabular}

but without high support (Fig. 7). ITS and combined analyses yielded a strongly supported monophyletic $C$. sect. Sylvaticae - $1.0 \mathrm{PP},>90 \%$ BS; Figs. 1,6 -, whereas ptDNA analysis showed a moderate support for the monophyly of $C$. sect. Sylvaticae $-0.91 \mathrm{PP},<50 \%$ BS (Fig. 7) - . The South African C. rainbowii was resolved as sister to the remaining lineages of the section $-C$. sylvatica and $C$. cretica - in the combined and nrDNA trees (Figs. 1, 6), with $C$. cretica being resolved as sister to $C$. sylvatica only in the combined analysis (Fig. 1). The 3 species collapsed in a basal polytomy in the ptDNA tree (Fig. 7). Carex sylvatica subsp. sylvatica and C. sylvatica subsp. paui were monophyletic but showed low support in the combined analysis - PP $<0.9$, BS 65\%
(Fig. 1) - , while their sequences collapsed in a polytomy in the nrDNA and ptDNA phylogenies (Figs. 6, 7). Interestingly, while $C$. sylvatica subsp. sylvatica was only recovered as monophyletic in the ptDNA tree $-0.99 \mathrm{PP}$, $81 \%$ BS (Fig. 7)-, C. sylvatica subsp. paui was strongly supported as a monophyletic group by all markers and analyses -1.0 PP, > 90\% BS (Figs. 1, 6, 7).

The calculated genetic distances (Table 4) revealed that C. sylvatica subsp. sylvatica -including the Navarran samples mentioned above - was more distantly related to C. sylvatica subp. paui - ITS 0.016 ; 5'trnK 0.007 ; concatenated sequences 0.009 - than to $C$. cretica - ITS 0.004 ; 5'trnK 0.005; concatenated sequences 0.006 - and to $C$. rainbowii for 5 'trn $\mathrm{K}$ sequences -0.003 .

\section{Morphological study}

For the sake of simplicity, and according to our molecular results, we considered the Navarran samples previously classified as C. sylvatica subsp. paui to belong to C. sylvatica subsp. sylvatica.

The PCA including only seven variables - SL, INFL, UL, UBL, SPKMN, SPKAN, and PAP (Table 2)revealed a clear separation between $C$. sylvatica subsp. sylvatica and C. sylvatica subsp. paui (Fig. 2). The first three principal components - PCs - accounted for $73.51 \%$ of 
Table 4. Pairwise genetic distances calculated for species pairs in C. sect. Sylvaticae.

\begin{tabular}{|c|c|c|c|c|}
\hline \multirow[t]{2}{*}{ Species compared } & & \multicolumn{3}{|c|}{ Genetic distance } \\
\hline & & ITS & $5 ' \operatorname{trnK}$ & Combined \\
\hline C. cretica & C. rainbowii & 0.022 & 0.002 & 0.018 \\
\hline C. cretica & C. laxula & 0.020 & 0.005 & 0.014 \\
\hline C. cretica & C. sylvatica subsp. sylvatica & 0.004 & 0.005 & 0.006 \\
\hline C. rainbowii & C. laxula & 0.039 & 0.003 & 0.014 \\
\hline C. rainbowii & C. sylvatica subsp. sylvatica & 0.022 & 0.003 & 0.012 \\
\hline
\end{tabular}
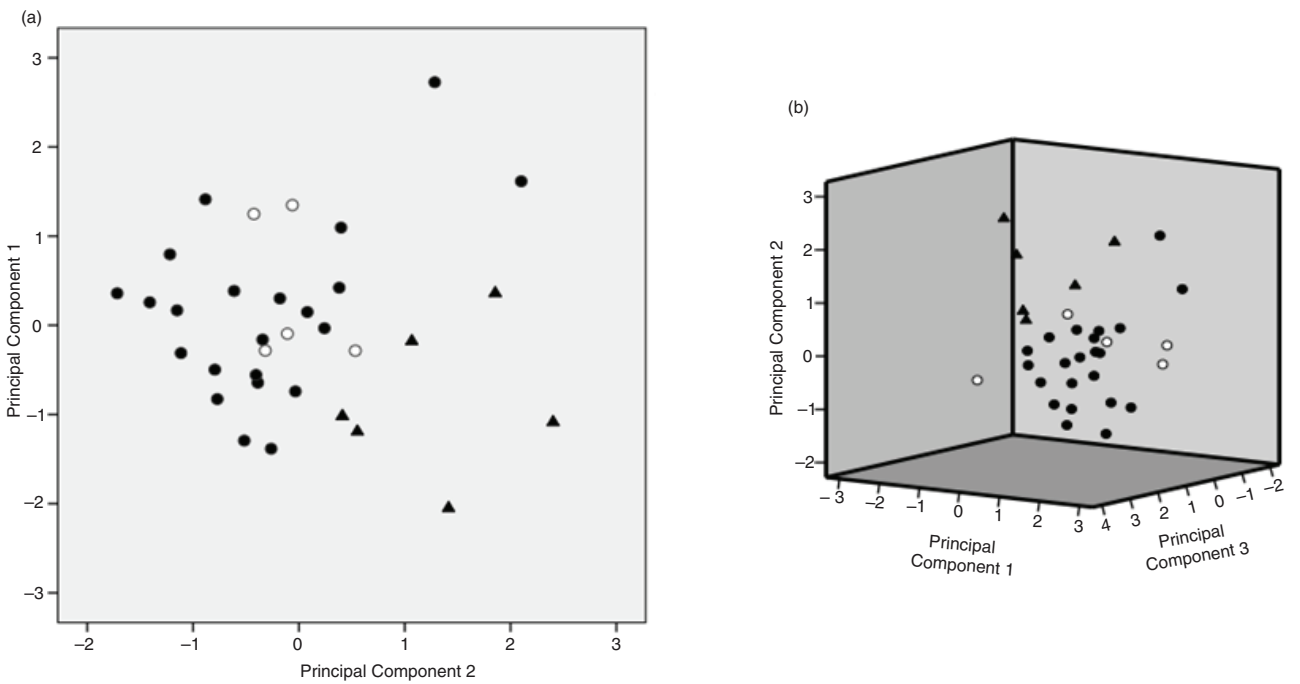

Fig. 2. Morphometric study: a, scatter plot of first and second principal components; $\mathbf{b}$, three first principal components extracted in the PCA analysis of the morphometric data. [C. sylvatica s.str. is represented by circles and C. laxula by triangles; empty circles depict these individuals of $C$. sylvatica s.str. previously classified as C. sylvatica subsp. paui.]

the total variance $-31.74 \%, 23.88 \%$ and $17.89 \%$ respectively-. The characters that contributed the most to the first 3 components were related to plant and utricle sizes, as well as the androgynous spike number (Table 6).

Boxplots showed that at least UL, UBL, SPKAN, and PAP displayed less than $25 \%$ overlap between the two studied taxa (Fig.3).

Table 5 summarizes those diagnostic characters that distinguish between both taxa according to our own results and previous studies (Luceño \& al., 2008; MartínBravo \& al., 2013).

\section{DISCUSSION}

\section{Carex sylvatica subsp. paui should be considered a distinct species: C. laxula}

Our molecular phylogenies revealed that the samples identified as $C$. sylvatica subsp. paui formed a wellsupported clade, sister to the $C$. sylvatica subsp. sylvatica clade in the combined tree (Fig. 1). Moreover, the genetic distance between these 2 taxa was larger than that found between $C$. sylvatica subsp. sylvatica and $C$. cretica (Table 4 ), being this latter taxon usually considered a separate species, morphologically distinct from any other member of $C$. sect. Sylvaticae (Escudero \& Luceño, 2009; Martín-Bravo \& al., 2013). In addition, the results retrieved by the morphometric study revealed a good degree of differentiation and a number of diagnostic characters separating the 2 taxa, despite the small number of specimens examined -including the type of C. laxula (Fig. 2) - . At least 4 characters displayed no or few $<25 \%$ - overlap (Fig 3, Table 2). The number of male spikes has been considered the most important and clear diagnostic character in previous studies (Table 5). Our study has revealed the existence of other important distinctive characters between both taxa: the number of androgynous spikes, the length of the stem, the inflorescence, the utricle, and the beak utricle, all of which are larger in $C$. sylvatica subsp. paui than in $C$. sylvatica subsp sylvatica (Fig.4). Also, the adaxial leaf surface is strongly rough in C. sylvatica subsp. paui, but smooth or slightly rough in $C$. sylvatica subsp sylvatica (Fig. 4, Table 5). Our data indicate that the taxon should be recognized at the species level. Based on the nomenclatural priority of the C. laxula name over C. paui Sennen, C. sylvatica subsp. paui is subsumed under C. laxula.

\section{Carex laxula new for the Balearic and Tuscan archipelagos and excluded from northern Spain}

Our study clearly shows that the studied specimens from the northeastern Spain - Catalonia - and the Balearic and Tuscan archipelagos, as well as the type specimen of 
Table 5. Main morphological characters differentiating C. sylvatica subsp. sylvatica from C. laxula, according to Martín-Bravo \& al. (2013) and the current study.

\begin{tabular}{lll}
\hline & C. sylvatica subsp. sylvatica & C. laxula \\
\hline Longest flowering stem $(\mathrm{cm})$ & 100 & 200 \\
Leaf upper side & Smooth to slightly rough & Strongly rough \\
Leaf width $(\mathrm{mm})$ & $(2) 4-7(8)$ & $(6) 8-14$ \\
Male spikes number & $1(2)$ & $(1) 2-4(7)$ \\
Female spike length $(\mathrm{mm})$ & $(23) 25-55$, not branched & $(22) 30-53$, sometimes branched at the base \\
Utricle length $(\mathrm{mm})$ & $(3.8) 4.0-5.0$ & $(4.0) 4.5-5.3$ \\
Utricle beak & Smooth, rarely with a few prickles towards the apex & Aculeolate \\
\hline
\end{tabular}

C. laxula formed indeed a well-characterized morphological taxon (Fig. 2). It is also in agreement with the phylogenetic nesting of the samples included in the molecular study (Figs. 1, 6, 7). By contrast, the Navarran samples previously classified as $C$. sylvatica subsp. paui fall within the variation of $C$. sylvatica subsp. sylvatica in both molecular and morphometric studies (Figs. 1,2) and should therefore be classified within the latter taxon.

Carex sylvatica subsp. paui was first described at the specific rank - C. paui Sennen (Sennen, 1925)—, but the taxon was later recognized at the subspecific rank $-C$. sylvatica subsp. paui (Sennen) Bolòs \& Bolòs- by Bolòs \& Bolòs (1950) and later authors (Luceño \& al., 2008; Jiménez-Mejías \& Luceño, 2011; Govaerts \& al., 2016). Early works indicated that the taxon was only known from Spain (Luceño, 1994; Luceño \& al., 2008). Later, the populations of $C$. algeriensis Nelmes from Algeria and Tunisia (Maire, 1957) were synonymized to C. sylvatica subsp. paui based on morphological data (Jiménez-Mejías \& Luceño, 2011; Martín-Bravo \& al., 2013). This treatment has been supported by our phylogenetic study - v.gr., the nesting of the Tunisian sample in the phylogenetic trees (Figs. 1, 7) - . The finding of C. sylvatica subsp. paui to be conspecific to C. laxula, from Sicily, and its new records from the islands of Mallorca - Balearic Islandsand Elba - Tuscan archipelago-, greatly expands the presence of this taxon in the western Mediterranean (Fig. 5). There were no previous reports of this species for the Balearic and Elba Islands (Pignatti, 1982; Innamorati, 1991; Bolòs \& Vigo, 2001; Conti \& al., 2005). It implies an important range expansion of C. laxula - C. sylvatica subsp. paui - in Spain and a new taxon for the Italian flora.

Misidentifications of C. laxula and C. sylvatica have been common as a consequence of the very subtle morphological differences between both taxa (Table 5). Thus, the finding of more populations of $C$. laxula in other adjacent areas of the western Mediterranean could be expected. The misidentification of the Navarran populations of $C$. sylvatica subsp. sylvatica as C. laxula - C. sylvatica subsp. paui (Luceño, 1994; Luceño \& al., 2008) - depicts a classical taxonomic problem. The Navarran individuals of C. sylvatica subsp. sylvatica display larger morphological variation than expected for the taxon (Global Carex Group, 2016). The detailed examination of these samples reveals that they show characters, such as a smooth upper side and margins of leaves, and the presence of only a few sparse prickles at the utricle beak, that match those detected in other studied samples of C. sylvatica subsp. sylvatica (Fig. 3). Nevertheless, these specimens also have a higher number of male and androgynous spikes and longer inflorescences than those usually found in C. sylvatica subsp. sylvatica, explaining previous misidentification of these plants.

\section{Ecology}

The ecology of $C$. laxula contrasts with that of $C$. sylvatica subsp. sylvatica. The latter taxon inhabits Eurosiberian and Atlantic forests, being part of the understory in broad-leaf deciduous woods of beech - Fagus sylvatica L.-, oaks - Quercus spp.-, and riparian forests, mostly on moist to wet soils on sandy or stony-clay substrates (Hegi, 1969; Luceño, 2008; Nilsson, 1985; Pignatti, 1982). In contrast, C. laxula mostly grows in shady humid Mediterranean forests dominated by evergreen oak - Quercus ilex L._- and Corylus avellana L. woods, as well as in riparian forests with Alnus glutinosa (L.) Gaertn. and Populus spp., mainly on siliceous substrates such as sandstones, at relatively low altitudes $-150-300 \mathrm{~m}$ s.n.m.(Maire, 1957; Luceño, 1994; Luceño \& al., 2008). The previous reports of $C$. laxula in beech forests - v.gr., $C$. sylvatica subsp. paui (Luceño, 1994; Luceño \& al., 2008) correspond to the Navarran populations here identified as C. sylvatica subsp. sylvatica, in agreement with the newly circumscribed niches of both taxa.

\section{Description}

We provide an updated description for C. laxula and an identification key to separate it from C. sylvatica subsp. sylvatica:

Carex laxula Tineo ex Boott, Carex 4: 202 (1867). TYPE: [Italia:] Sicily, Palermo, 1867, V. Tineo s.n. [lectotype, here designated: BM 001067082!]. Iconography: Luceño \& al. (2008: 166).

C. algeriensis Nelmes, Bull. Misc. Inform. Kew 1939: 99 (1939). C. sylvatica subsp. algeriensis (Nelmes) Maire \& Weiller, Fl. Afrique N. 4: 154 (1957). [Algeria:] Yacoûren, between Bougie and Tizi Ouzou, ravine in deciduous oak forest, 27 April 1937, Alston \& Simpson 37614 [lectotype, designated here: K 000363433 photo!; isotypes: BM 000922723 photo!, BM 000922724 photo!].

C. paui Sennen, Exsicc. Pl. Espagne 1925: $\mathrm{n}^{\circ} 5435$ (1925). C. sylvatica subsp. paui (Sennen) A. Bolòs \& O. Bolòs in Bolòs, Veg. Com. 
(a)
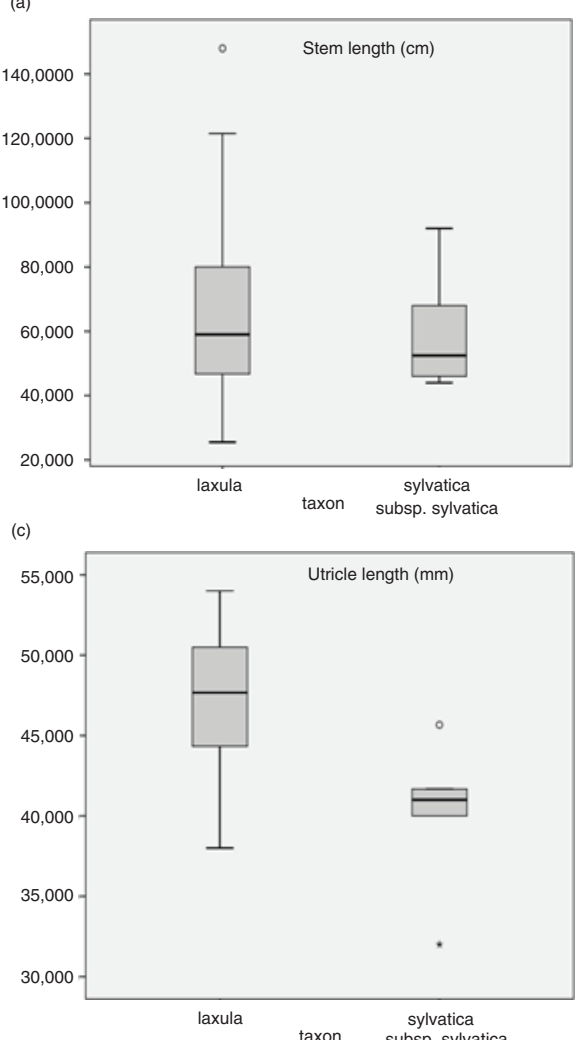

(e)

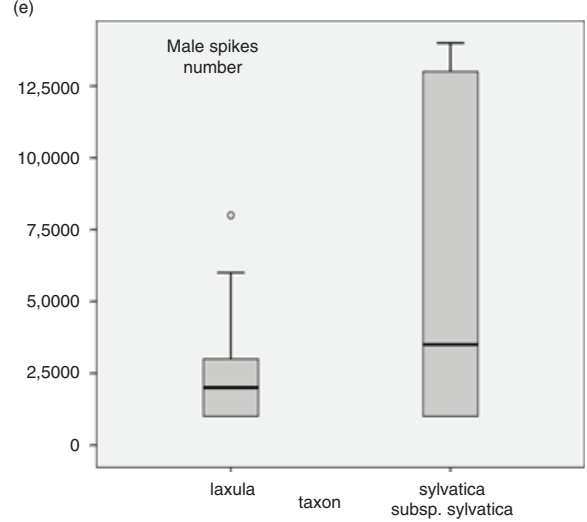

(b)

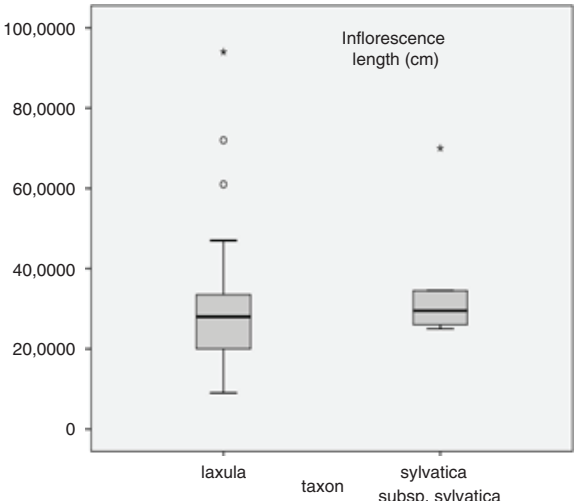

(d)

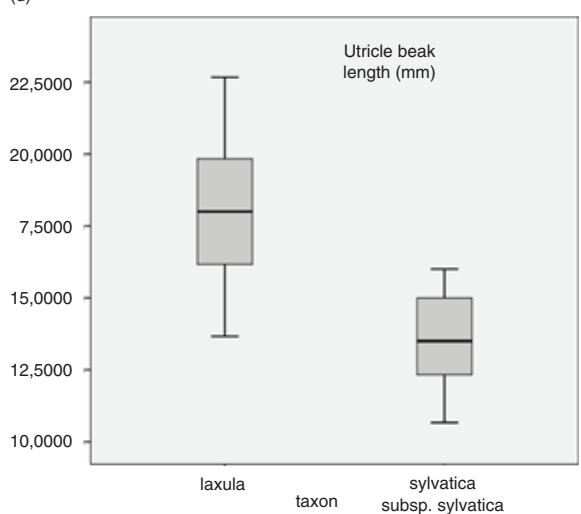

(f)

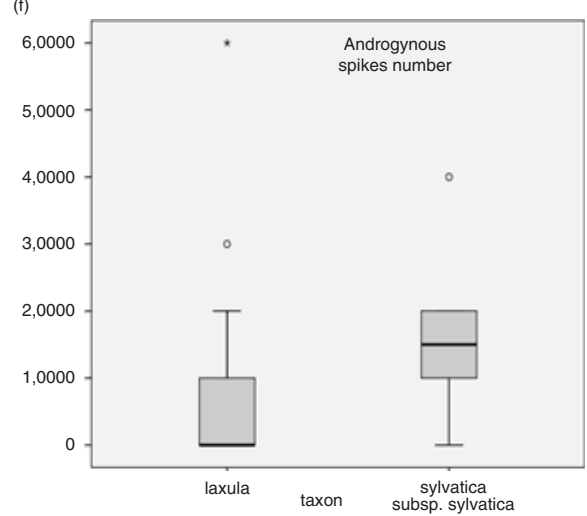

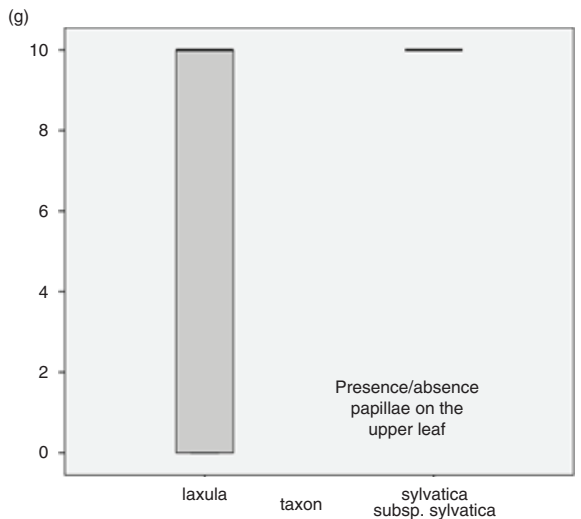

Fig. 3. Statistic boxplots of main morphological characters retrieved by PCA analyzed in the studied C. laxula and C. sylvatica subsp. sylvatica samples. 
Barcelon.: 246 (1950). [Spain:] Barcelone, massif du Tibidabo, dans les barrancos, 6 June 1925, Fr. Sennen $n .^{\circ} 5435$ [lectotype, designated by Luceño \& al. (2008): MA 18049!; isotype: MA 417028!].

Caespitose plant. Flowering stems up to $200 \mathrm{~cm}$ long, sharply trigonous, smooth. Inflorescences length 25-35(70) $\mathrm{cm}$. Leaves 10-14 mm wide, shorter than stems,

Table 6. Variables included in the PCA (abbreviations specified in Table 2)

\begin{tabular}{lccc}
\hline & \multicolumn{3}{c}{ Component } \\
\cline { 2 - 4 } Variable & $\mathbf{1}$ & $\mathbf{2}$ & $\mathbf{3}$ \\
\hline SL & 0.719 & 0.546 & -0.309 \\
INFL & 0.736 & 0.560 & -0.225 \\
UL & 0.706 & -0.563 & 0.263 \\
UBL & 0.793 & -0.446 & 0.333 \\
SPKMN & -0.023 & 0.458 & 0.084 \\
SPKAN & 0.068 & 0.413 & 0.729 \\
PAP & -0.176 & 0.404 & 0.623 \\
\hline
\end{tabular}

\pm carinate, \pm rigid, with the adaxial surface scabrid; ligule 1.5-3(5) $\mathrm{mm}$ long, longer than wide, apex obtuse; basal sheaths pale brown, entire, rarely fibrous. Lowermost bract shorter than the inflorescence. Male spikes (1)24(7), 14-45 mm long, fusiform, sometimes with a few utricles at the base, very rarely with utricles also at the top. Female spikes 3-4, (22)30-53 mm long, occasionally shortly branched at the base, at least the lower ones separated from the upper ones, with long filiform and pendant peduncles, the upper ones with shorter peduncles, sometimes arising very close to each other. Androgynous spikes (0)1-2(4). Male glumes oblong to obovate, light brown, acute, subacute or obtuse, rarely mucronate; female glumes elliptic, shorter than the utricles, hyaline or, exceptionally, pale brown with a wide scarious margin. Utricles 4-4.5 × 1-1.2(1.5) mm, suberect, ovoid, trigonous, greenish or brownish, with only 2 prominent veins, more or less abruptly contracted into a narrow, slender, bifid beak, 1.2-2(2.3) mm long, conspicuously scabrid, with prickles towards the top. Achenes (2)2.2-2.5 $\times$ 0.9-1.4 $\mathrm{mm}$, ovoid, trigonous, greenish to pale brown.

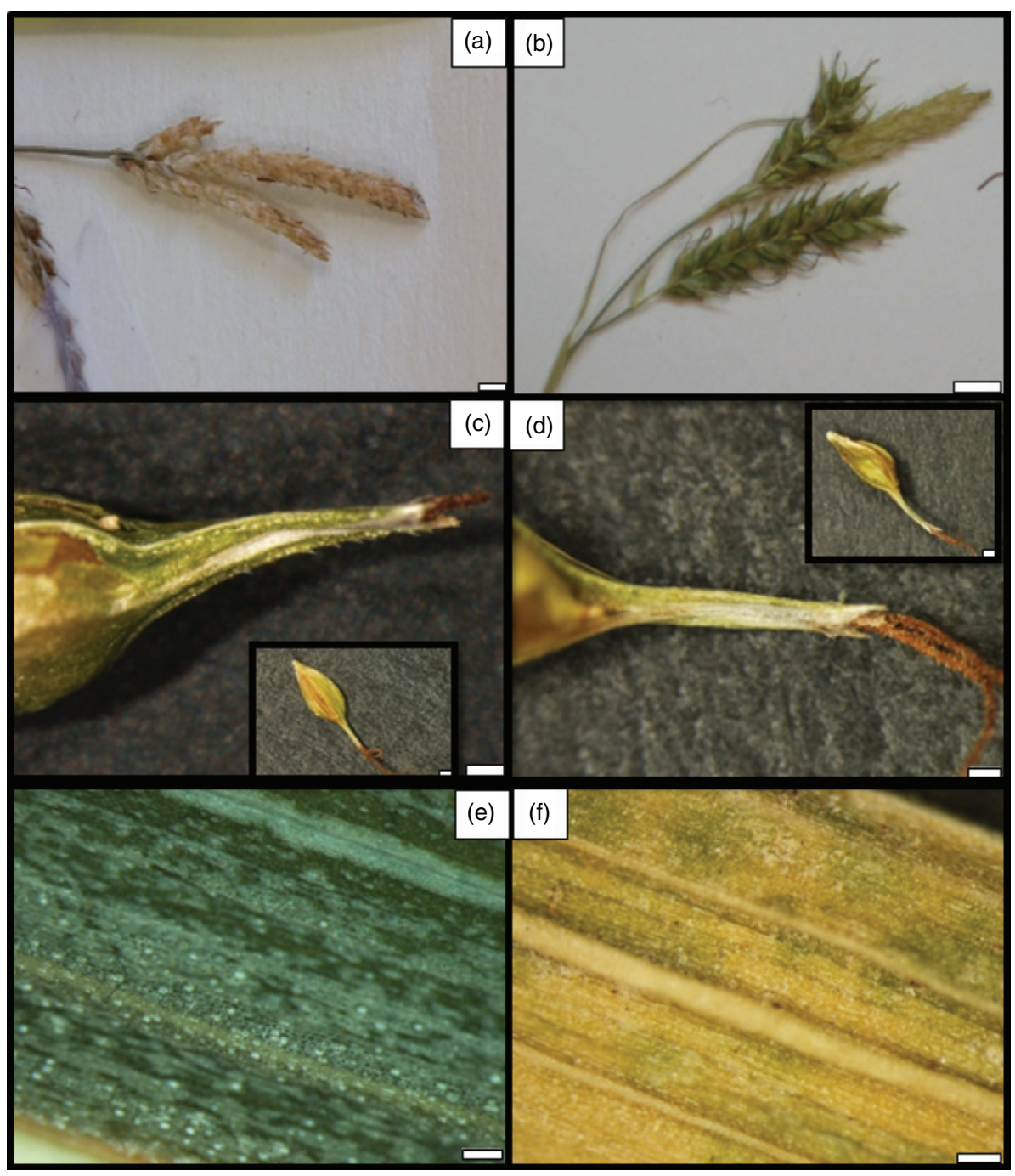

Fig. 4. Detailed photographs of diagnostic characters separating C. laxula - left column - and C. sylvatica subsp. sylvatica - right column-: a, b, male spike(s) of the inflorescence; $\mathbf{c}, \mathbf{d}$, utricle beak and complete utricle (inset); $\mathbf{e}, \mathbf{f}$, leaf upper side. [Scale bars: $\mathrm{a}, \mathrm{b}=0.5 \mathrm{~mm} ; \mathrm{c}, \mathrm{d}=0.2 \mathrm{~mm}(0.1 \mathrm{~mm}$ in inset); e = $0.2 \mathrm{~mm} ; \mathrm{f}=0.1 \mathrm{~mm}$. Specimens: a, J. Höller s.n. (M 0223070); c, e, P. Jiménez-Mejías \& al. 76PJM13 (UPOS 6141); b, d, f, M. Luceño \& al. $1608 M L$ (UPOS 3427).] 


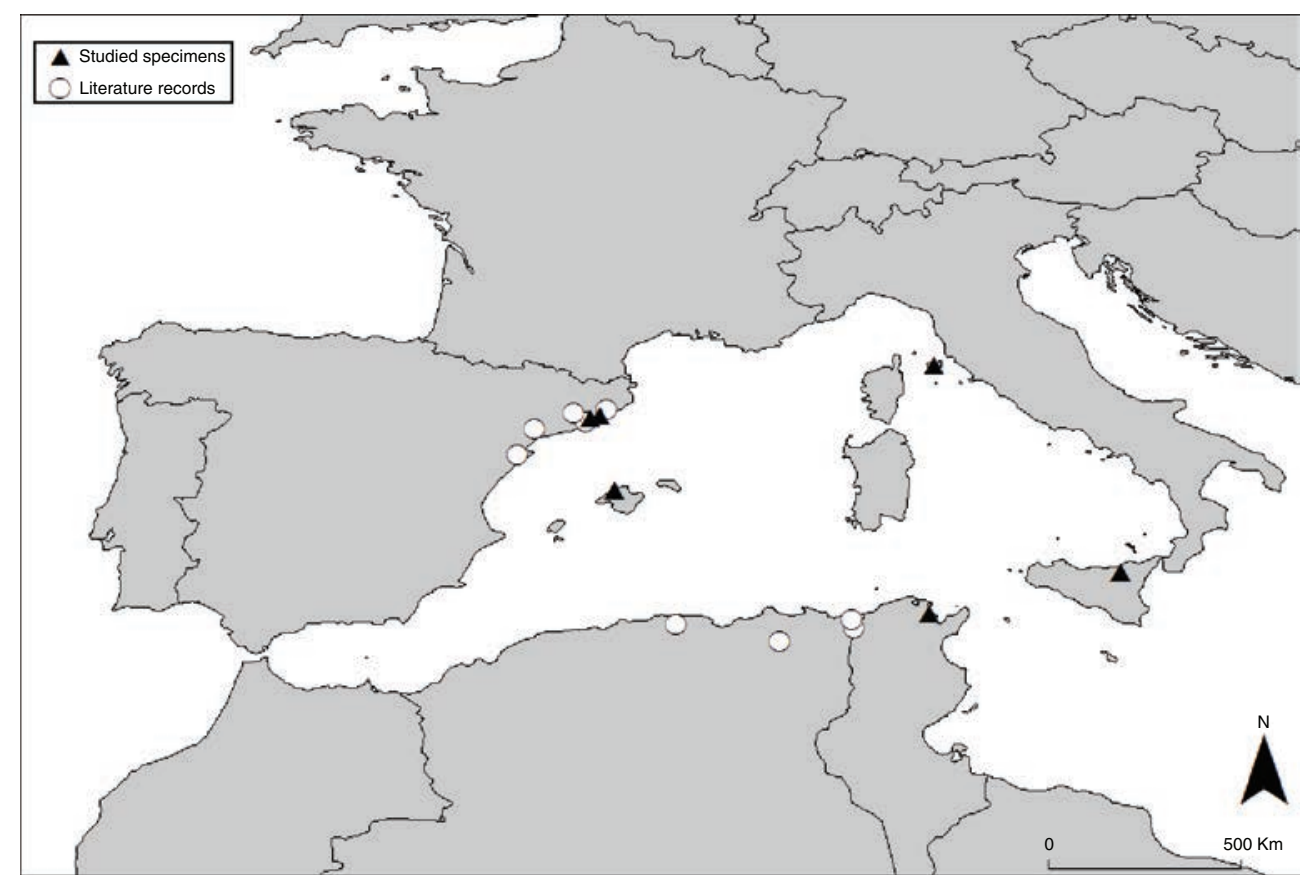

Fig. 5. Known distribution of C. laxula. [Studied populations are represented by black triangles and literature records by white circles.]

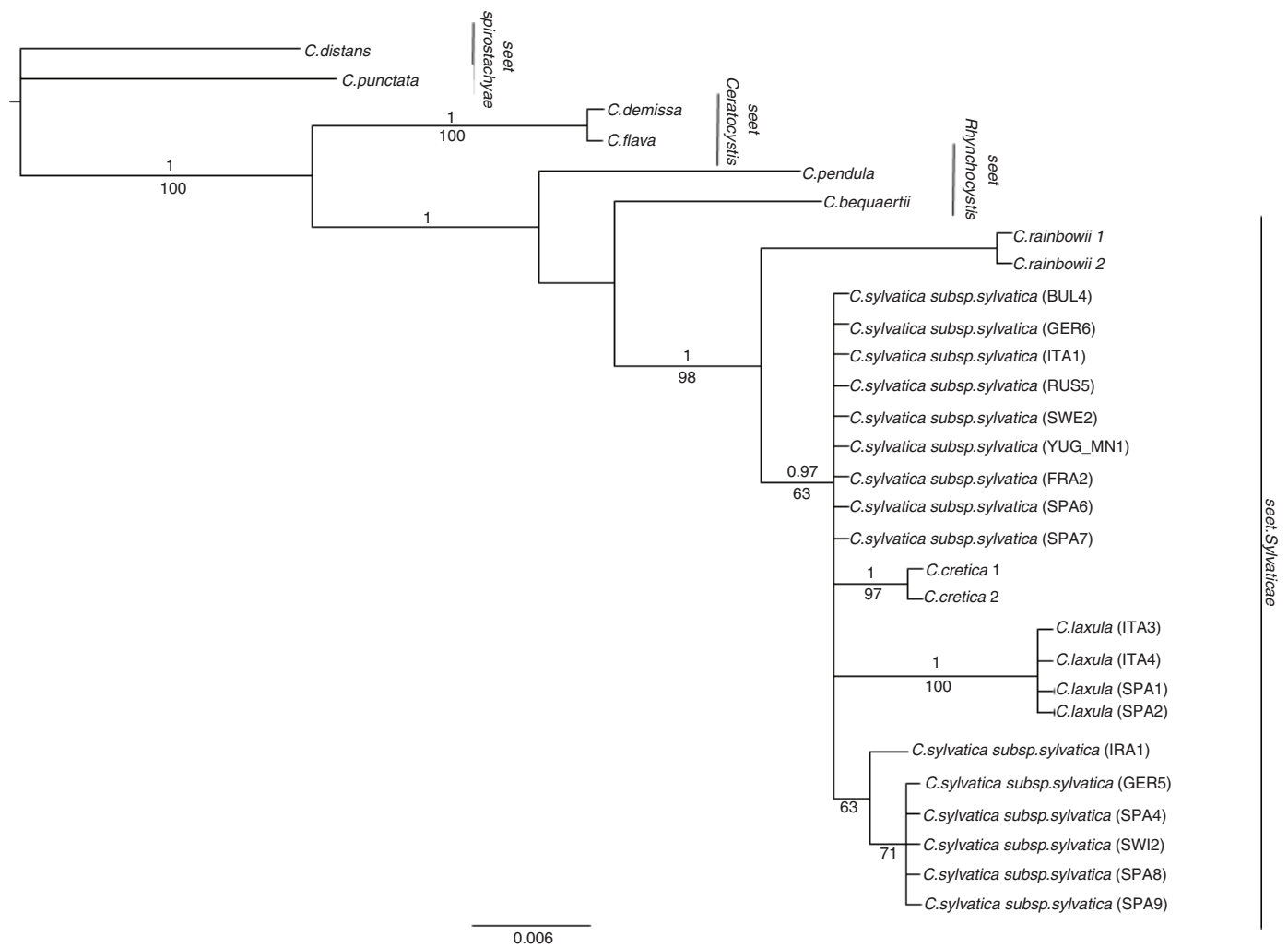

Fig. 6. Bayesian phylogenetic tree obtained from the analysis of the $\operatorname{nrDNA}$ ITS sequences for $C$. sect. Sylvaticae -incl. $C$. cretica, $C$. laxula, $C$. rainbowit, and C. sylvatica subsp. sylvatica - and closely related sections - C. sect. Ceratocystis, C. sect. Spirostachyae, and C. sect. Rhynchocystis[29 samples were included in this analysis; numbers above or below branches correspond to the posterior probability $-\mathrm{PP}>0.9$, above branches - and Bootstrap support — BS $>50 \%$, below branches — values.] 


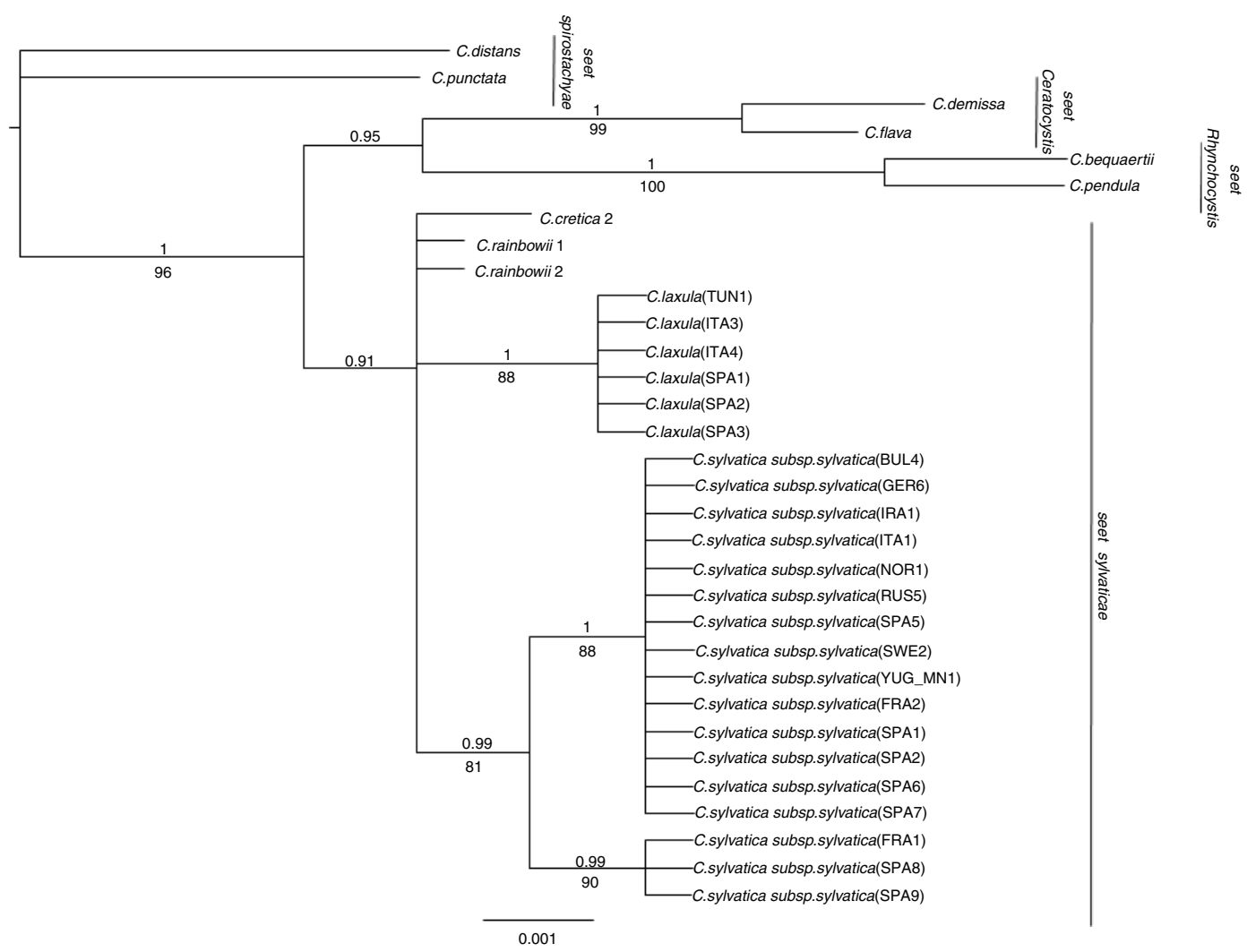

Fig. 7. Bayesian phylogenetic tree obtained from the analysis of the ptDNA 5'trnK sequences for C. sect. Sylvaticae -incl. C. cretica, C. laxula, C. rainbowii, and C. sylvatica subsp. sylvatica - and closely related sections - C. sect. Ceratocystis, C. sect. Spirostachyae, and C. sect. Rhynchocystis[32 samples were included in this analysis; numbers above or below branches correspond to the posterior probability - PP $>0.9$, above branches - and Bootstrap support — BS > 50\%, below branches — values.]

\section{Distribution and notes}

It is a western Mediterranean endemic: northeastern Iberian Peninsula, Balearic Islands, Elba Island, Sicily, northern Algeria, and northern Tunisia (Fig. 5).

One of the isolectotype specimens we listed for C. algeriensis housed at BM - BM 000922724 displays a label that says it was collected in May -5instead of April, as indicated in the protologue and other specimens. However, the collector number - 37614 , and also the day of the month - 27- and year - 1937-, are the same. We consider that the difference in the label is just a typo when transcribing the new label, thus the material should be considered an isolectotype.

\section{Identification key}

1. Male spikes 1(2); androgynous spikes absent or very rarely 1-2(3); utricle beaks smooth, very rarely with a few sparse prickles at the tip; leaves soft, smooth to slightly scabrid on the upper side and the margins ............................ C. sylvatica subsp. sylvatica

2. Male spikes (1)2-4(7); androgynous spikes 1-4, very rarely absent; utricle beaks conspicuously scabrid, with prickles towards the top; leaves \pm rigid, conspicuously scabrid on most of the upper side

\section{ACKNOWLEDGEMENTS}

This work was carried out with financial support from CGL2012-38744 project from the Spanish Ministry of Economy and Competitiveness. The authors wish to thank F.J. Fernández Martín and his assistants for technical herbarium support, Professor M. Luceño for his useful comments about the taxonomy of the group, support and guidance, the curators and staff of ARAN, JACA, M, UPOS, UPS, and $\mathrm{BM}$ herbaria for sending us type or representative material on loan, G.E. Rodríguez-Palacios for technical support when studying M collection, the California Academy of Sciences - San Francisco, California, USA - for the use of the Phylocluster, and associate editor and three anonymous referees for their valuable comments to an early version of the manuscript.

\section{REFERENCES}

Aizpuru, I., Aseguinolaza, C., Uribe-Echebarría, P.M., Urrutia, P. \& Zorrakín, I. (eds.) 1999. Claves ilustradas de la flora del País Vasco y territorios limitrofes. Servicio Central de publicaciones del Gobierno Vasco, Vitoria.

Bolòs, O. \& Vigo, J. 2001. Flora dels Països Catalans vol. 4. Institut d'Estudis Catalans, Barcelona.

Chater, A.O. 1980. Carex. In: Tutin, T.G., Heywood, V.H., Burges, N.A., Moore, D.M., Valentine, D.H., Walters, S.M., Webb, D.A. (eds.), Flora Europaea 5: 290-323. Cambridge Univ. Press, Cambridge.

Conti, F., Abbate, G., Alessandrini, A. \& Blasi, C. 2005. An annotated checklist of the Italian vascular flora. Palombi, Roma.

Egorova, T.V. 1999. The sedges (Carex L.) of Russia and adjacent states (within the limits of the former USSR): 772. St. Petersburg State Chemical-Pharmaceutical Academy, St. Petersburg. 
Escudero, M. \& Luceño, M. 2009. Systematics and Evolution of Carex sects. Spirostachyae and Elatae (Cyperaceae). Plant Systematics and Evolution 279: 163-189. https://doi.org/10.1007/s00606-009-0156-x.

Escudero, M., Valcárcel, V., Vargas, P. \& Luceño, M. 2008. Evolution in Carex L. sect. Spirostachyae (Cyperaceae): A molecular and cytogenetic approach. Organisms, Diversity \& Evolution 7: 271-291. https:// doi.org/10.1016/j.ode.2006.08.006.

Global Carex Group. 2015. Making Carex monophyletic (Cyperaceae, tribe Cariceae): a new broader circumscription. Botanical Journal of the Linnean Society 179: 1-42. https://doi.org/10.1111/boj.12298.

Global Carex Group. 2016. Megaphylogenetic specimen-level approaches to the Carex (Cyperaceae) phylogeny using regions ITS, ETS, and matK: implications for classification. Systematic Botany 41: 500-518. https://doi.org/10.1600/036364416X692497.

Govaerts, R., Jiménez-Mejías, P., Koopman, J., Simpson, D.A., Bruhl, J., Egorova, T.V., Goetghebeur, P. \& Wilson, K. 2016. Word checklist of Cyperaceae http://apps.kew.org/wcsp/home.do.

Hegi, G. 1969. Illustrierte Flora von Mitteleuropa 3(2): 161-240. München.

Innamorati, T.F. 1991. La Flora vascolare dell'Isola d'Elba (Arcipelago Toscano). Parte terza. Webbia 45: 137-185. https://doi.org/10.1080/00 837792.1991.10670494.

Jiménez-Mejías, P. \& Luceño, M. 2009. Carex castroviejoi Luceño \& Jiménez-Mejías (Cyperaceae), a new species from north Greek mountains. Acta Botanica Malacitana 34: 231-233.

Jiménez-Mejías, P. \& Luceño, M. [2011]. Cyperaceae. In: Euro + Med Plantbase - the Information Resource for Euro-Mediterranean Plant Diversity [http://ww2.bgbm.org/EuroPlusMed/query.asp.]

Jiménez-Mejías, P., Luceño, M. \& Castroviejo, S. 2007. Schoenoplectus corymbosus: a tropical Old-World sedge (Cyperaceae) discovered in Spain and Morocco. Nordic Journal of Botany 25: 70-74. https://doi. org/10.1111/j.0107-055X.2007.00007_26.x.

Jiménez-Mejías, P., Martín-Bravo, S. \& Luceño, M. 2012. Systematic and taxonomy of Carex sect. Ceratocystis (Cyperaceae) in Europe: a molecular and cytogenetic approach. Systematic Botany 37: 382-398. https://doi.org/10.1600/036364412X635449.

Luceño, M. 1994. Cytotaxonomic studies in Iberian, Balearic, North African, and Macaronesian species of Carex (Cyperaceae). II. Canadian Journal of Botany 72: 587-596. https://doi.org/10.1139/b94-078.

Luceño, M. 1994. Monografía del género Carex en la Península Ibérica e Islas Baleares. Ruizia 14: 1-144.

Luceño, M. Escudero, M. \& Jiménez-Mejías, P. 2008. Carex (Cyperaceae). In: Castroviejo, S. \& al. (eds), Flora iberica 18: 109-250. CSIC, Madrid.

Maire, R. 1957. Flore de l'Afrique du Nord vol. 4. Paul Lechevalier, Paris.
Martín-Bravo, S., Escudero, M., Míguez, M., Jiménez-Mejías, P. \& Luceño, M. 2013. Molecular and morphological evidence for a new species from South Africa: Carex rainbowii (Cyperaceae). South African Journal of Botany 87: 85-91. https://doi.org/10.1016/j. sajb.2013.03.014.

Nilsson, Ö. 1985. Carex L. In: Davis, P. (ed.), Flora of Turkey 9:73-158. Edinburg University Press, Edinburg.

Pignatti, S. 1982. Flora d'Italia. Edagricole, Bologna.

Reznicek, A. 1990. Evolution in Sedges (Carex, Cyperaceae). Canadian Journal of Botany 68: 1409-1432. https://doi.org/10.1139/ b90-180.

Ronquist, F. \& Huelsenbeck, J.P. 2003. Mr Bayes 3: Bayesian phylogenetic inference under mixed models. Bioinformatics 19: 1572-1574. https://doi.org/10.1093/bioinformatics/btg180.

Stamatakis, A. 2010. RAxML-VI-HPC: Maximum Likelihood-based Phylogenetic Analyses with Thousands of Taxa and Mixed Models. Bioinformatics 22: 2688-2690. https://doi.org/10.1093/bioinformatics/ bt1446.

Swofford, D. 2002. PAUP*: Phylogenetic analysis using parsimony (*and other methods), version 4. Sinauer, Sunderland, Massachusetts, USA.

Tamura, K., Peterson, D., Peterson, N., Stecher, G., Nei, M. \& Kumar, S. 2011. MEGA5: Molecular Evolutionary Genetics Analysis using Likelihood, Distance, and Parsimony methods. Molecular Biology and Evolution 10: 2731-2739. https://doi.org/10.1093/ molbev/msr121.

Thiers, B. [2015]. Index Herbariorum [http://sweetgum.nybg.org/science/ $\mathrm{ih} /$.

Verloove, F. \& Mesterházy, A. 2013. Cyperus glaber L. (Cyperaceae), an enigmatic species "new" to Spain. Webbia 68: 67-71. https://doi. org/10.1080/00837792.2013.801110.

Verloove, F. \& Saiani, D. 2015. Studies in Italian Cyperaceae: 3. Cyperus erythrorhizos, new to Europe, naturalized in Italy. Webbia 70: 133-137. https://doi.org/10.1080/00837792.2015.1004871.

Villaverde, T., Escudero, M., Martín-Bravo, S., Bruederle, L.P., Luceño, M. \& Starr, J.R. 2015. Direct long-distance dispersal best explains the bipolar distribution of Carex arctogena (Carex sect. Capituligerae, Cyperaceae). Journal of Biogeography 42: 1514-1525. https://doi. org/10.1111/jbi.12521.

Waterway, M.J. \& Starr, J.R. 2007. Phylogenetic relationships in tribe Cariceae (Cyperaceae) based on nested analyses of four molecular data sets. Aliso 23: 165-192. https://doi.org/10.5642/ aliso.20072301.13 
APPENDIX 1. Herbarium materials of C. sylvatica subsp. sylvatica and $C$. laxula included in the morphological and molecular studies. Data between square brackets indicate the specimens also included in the molecular study -including sample labeling in the phylogeny, and ITS and 5'trnK Genbank accession numbers for the new sequences generated in this study; if a marker is missing, it is replaced by a dash-. Asterisks depict those samples included in the molecular study but not in the morphometric study. Herbaria acronyms follow Index Herbariorum (Thiers, 2015).

Carex sylvatica subsp. sylvatica. ARMENIA. Lori: Pushkin pass, G. Fayvush \& al. 03-0537 (MSB 123515). BOSNIA-HERZEGOVINA. Magli: P. Orendi s.n. (M 0183079). BULGARIA. Central Balkans: P. Jiménez-Mejías \& F. Madroñal 113 PJM10 (UPOS 4054); ibidem, P. Jiménez-Mejías \& F. Madroñal 109PJM10 (UPOS 4049) [BUL4; KU242691, KU242704]*.

CROATIA. Umag S.: J. Höller s.n. (M 0183078).

DENMARK. Odense: H.F. Poulsen s.n. (V 572147).

FRANCE. Atlantic Pyrenees: Pau Urdos, Espelunguère, Les Forges d'Abel, P. Montserrat s.n. (JACA 227895) [FRA2; KX426304, KX426309]; Haute-Normandie: Eure, P. Jiménez-Mejías 16PJM10 (UPOS 4112) [FRA1; -, KC122386]*.

HUNGARY. Budapest: Ungvár, P. Erzberger 3-1615 (B 100343844). GERMANY. Bavaria: Münich, P. Jiménez-Mejias \& G. E. RodríguezPalacios 171 PJM13 (UPOS 5559) [GER6; KU242692, KU242705]*. IRAN. Tangerah: Golestan National Park, H. Akhani 10385 (M 0183092) [IRA1; KU242693, KU242706].

ITALY. Abruzzo: Central Apennines, Monti Della Laga National Park, P. Jiménez-Mejías \& al. 246PJM10 (UPOS 4133) [ITA1; KU242694, KU242707]. Piedmont: colina di Turín, P. Jiménez-Mejías \& E. Martinetto 113PJM12-2 (UPOS 5350); ibidem, ponte dei Preti, $P$. Jiménez-Mejías \& E. Martinetto 63PJM12-2 (UPOS 5347).

MONTENEGRO. Durmitor National Park: Zabljak, P. JiménezMejías 228PJM10 (UPOS 4026) [YUG-MN1; KU242702, KU242716]. NORWAY. Asker: Konglungen, P. Jiménez-Mejías \& K. Lye 188PJM09 (UPOS 4547) [NOR1; -, KC122387].

POLAND. Upper Silesia: Rybnik, Krystof 10362 (B 100118074).

ROMANIA. Cotofanesti: D. Mititelu \& al. s.n. (M 0183082).

RUSSIA. Kazan: Semenenko \& Nekrasova s.n. (B 100448059).

Moscow: Bei Dorf Weschke, A.K. Skvortsov s.n. (M 0183087) [RUS5;

(KU242700, KU242712]*.

SERBIA. Carpatians: Djerdap, P. Jiménez-Mejías 83 PJM10 (UPOS 4204).

SOUTH AFRICA. Western Cape: Knysna Diov, G. Lindeberg s.n. (V 571678)
SPAIN. Jaén: Siles, Las Acebeas, S. Martín-Bravo \& al. 121 SMB15 (UPOS 6320) [SPA8; KX426307, KX426314]. Gerona: Olot, La Moixina, P. Jiménez-Mejías \& al. 106PJM13 1/2 (UPOS 5270) [SPA2; -, KX426311]*. Huesca: Ansó, P. Montserrat s.n. (JACA 80782) [SPA6; KX426305, KX426312]; National Park Ordesa, M.L. Buide \& J.M. Marin s.n. (UPOS 161) [SPA5; -, KU242714]*. Lérida: Les Bordes, Artiga de Lin, E. Maguilla \& M. Luceño 39EMS12 (10) 1/2 (UPOS 5048) [SPA1; -, KX426310]. Palencia: Piedrasluengas, J.M. Marín \& al. 14004JMM (UPOS 163) [SPA4; KU242699, -]*.

SWEDEN. Öland: Högsrum, C.M. Norrman s.n. (V 572178). Västergötland: Västra Tunhem, J. Sjögren s.n. (V 572152) [SWE2; KU242701, KU242715]*.

Carex sylvatica subsp. sylvatica - materials erroneously classified as C. sylvatica subsp. paui-. SPAIN. Navarra: Artikutza, I. Aizpuru \& P. Catalán s.n. (ARAN 22918); Foz de Arbayun, J. \& G. Montserrat 87-JACA-0911-08102 (JACA 810287) [SPA9; KX426308, KX426315]; Garralda, G. \& J. Montserrat s.n. (JACA 797187); Isaba, L. Villar s.n. (JACA 10045273) [SPA7; KX426306, KX426313]; Ochagavia, L. Villar \& G. Montserrat s.n. (JACA 118787).

Carex laxula -including materials previously classified as C. sylvatica subsp. paui-. ITALY. Sicily: 1877, V. Tineo s.n. (BM 001067082; C. laxula lectotype). Tuscany: Elba, J. Höller s.n. (M 0223069) [ITA3; KU242695, KU242708]; Elba, Mt. Perone, J. Höller s.n. (M 0223070) [ITA4; KU242696, KU242709].

SPAIN. Catalonia: Barcelona, Massif du Tibidabo, 1925, Fr. Sennen $n^{\circ} 5435$ (C. paui lectotype, MA 18049, isolectotype MA 417028); Montnegre, P. Jiménez-Mejías \& al. 85PJM13 1/13 (UPOS 6142) [SPA1; KU242697, KU242710]; Sant Carles, P. Jiménez-Mejías \& al. 76PJM13 1/4 (UPOS 6141) [SPA2; KU242698, KU242711]. Balearic Islands: Mallorca, Lluch, H. Merxmüller \& W. Wiedmann 7709 (M 0223072) [SPA3; -, KU242713].

TUNISIA. Medjerda: Bei Les Chênes, H. Hertel 8305 (M 0183088) [TUN1; -, KU242703]*.

APPENDIX 2. Accession numbers for ITS and 5'trnK sequences downloaded from Genbank and included in the molecular study.

Carex bequaertii: EU288572, KC122385; C. cretica 1: DQ384117; C. cretica 2: DQ384118, EU812677; C. demissa: AY278307, JN627690; C. distans: EU483663, JN627754; C. flava: AF285007, JN627705; C. pendula: AY757600, KC122384; C. punctata: DQ384180, EU812618; C. rainbowii 1: KC122380, KC122382; C. rainbowii 2: KC122381, KC122383; C. sylvatica subsp. sylvatica GER5: AY278306; C. sylvatica subsp. sylvatica SWI2: AY757599. 